\title{
Filip Jankowski*
}

\section{Rozrachunek z przeszłością historyczną Francji na przykładzie gier Lankhoru}

\section{Wprowadzenie}

W niniejszym artykule chciałbym poświęcić uwagę dwóm grom francuskiej wytwórni Lankhor, które na przełomie lat 80. i 90. XX wieku - jak się zdaje - włączyły się do dyskusji nad skazami na wizerunku historycznym państwa francuskiego. Le Manoir de Mortevielle (Lankhor 1987) oraz Maupiti Island (Lankhor 1990) pozornie nie odnoszą się bezpośrednio do przeszłości Francji. Jednakże, jak będę starał się wykazać, obie gry odsłaniają swoje drugie dno. Celem artykułu jest unaocznienie, w jaki sposób przeszłość historyczna państwa francuskiego mogła być poddawana rewizji w grach cyfrowych, nawet w formie zawoalowanej.

Wybór gier Lankhoru jako materiału badawczego uzasadniam wieloma czynnikami. Przede wszystkim obie odwołują się ostentacyjnie do wspomnianej przeszłości (ich akcja przypada odpowiednio na rok 1951 i 1954). W obu też głównym bohaterem jest prywatny detektyw Jérôme Lange, stylizowany na Humphreya Bogarta z kina noir, co jeszcze bardziej podkreśla ich odniesienia do przeszłości. Ponadto akcja obu gier toczy się na terenie Francji: Mortevielle rozgrywa się na prowincji niedaleko Paryża, natomiast Maupiti Island - na tytułowym atolu na Polinezji Francuskiej. Wreszcie zaś w obu grach można dostrzec dysonans pomiędzy nostalgicznym powierzchniowym tonem a relatywizacją przeszłości, który w odniesieniu do literatury i kina francuskiego lat 70, XX wieku doczekał się określenia la mode rétro (Morris 1992; Jameson 1996, 198; Austin 2008, 29-33).

Od momentu publikacji filmu Lacombe Lucien (Malle, 1974) przez Francję przetoczyła się fala rozliczeń z historią faszystowskiego państwa Vichy, które po niemie-

* Uniwersytet Jagielloński, Wydział Zarządzania i Komunikacji Społecznej; e-mail: filip.jankowski@doctoral.uj.edu.pl 
ckiej agresji i kapitulacji Republiki Francuskiej w 1940 roku wspierało III Rzeszę w działaniach wojennych i ludobójstwie Żydów (Gołuński 2015, 975-977). O ile po II wojnie światowej stronnictwo Charles’a de Gaulle’a wymazywało ze zbiorowej pamięci okres niechlubnej kolaboracji i zastąpiło go mitem powszechnego ruchu oporu, znanym jako résistencialisme (Jackson 2011, 601-604), o tyle zainicjowana przez Lacombe'a Luciena dyskusja spowodowała wyłonienie się nowego konsensusu. Ten zaś wskazywał, że o ile na początku wojny kolaboracja była powszechna, dopiero z upływem czasu Francuzi stopniowo zaczęli wspierać ruch oporu (Austin 2008, 30). Równocześnie Francja zmagała się z narastającą krytyką ze względu na jej uwikłanie w dyskurs kolonialny i rasistowską postawę wobec ujarzmionych przed 1945 rokiem first nations w Afryce, Azji i Oceanii (Alloula 1986; Aldrich 1990), której przejawy już w latach 50. martynikański pisarz Aime Césaire zgrabnie ujmował jako „zabijanie w Indochinach, torturowanie na Madagaskarze, więzienie w Czarnej Afryce, pacyfikowanie w Zachodnich Indiach" (Césaire 1972, 9-10).

Niniejszy artykuł ma charakter interpretatywny. Posłużę się w nim terminologią Ólivera Péreza-Latorrego, Mercè Oliwy i Reinalda Besalú (2017), którzy proponują społeczno-semiotyczny model składający się z badania narracji audiowizualnej w wymiarze ludonarracyjnym [ludo-narrative], systemowym [system-gameplay] oraz zachodzącym na linii projektant-gracz [Designer-Player], a także zestawienia tychże wymiarów z kontekstem społecznym. W tej analizie jednak skupię się na narracji audiowizualnej (zawartości tekstowej oraz wizualnej) oraz na proponowanych przez Péreza-Latorrego, Olivę i Besalú ludonarracyjnych czynnikach obydwu gier, mianowicie reprezentacji postaci/gracza, świata fikcyjnego oraz sprawczości, odnosząc je do kontekstu społecznego.

\section{Słowo o Lankhorze}

Lankhor początkowo składał się z dwóch przedsiębiorstw: wytwórni Kyilkhor prowadzonej przez Bruno Gouriera oraz autorskiej spółki małżeństwa Béatrice i Jeana-Luca Langlois. W 1986 roku trójka przedsiębiorców połączyła siły, a rok później nastąpiła fuzja ich spółek (Coulon 1989). Spajająca w sobie nazwy obojga przedsiębiorstw wytwórnia Lankhor przeżyła szczyt popularności na przełomie lat 8o. i 9o. XX wieku, łącznie produkując blisko 40 gier, w tym kilka horrorów (Lankhor.net b.d.). Jednakże to Le Manoir de Mortevielle oraz Maupiti Island odniosły największy sukces, przypieczętowany nagrodami branżowymi Tilt d'Or dla najlepszych gier „przygodowych” roku (Brisou 1987; Hautefeuille 1990).

Autorami pierwotnej wersji Le Manoir de Mortevielle, zaprogramowanej na niszowym komputerze Sinclair QL, byli Gourier oraz jego współpracownik Bernard Grelaud. W stosunku do późniejszych wersji (na Amstrada CPC, Atari ST, Amige oraz MS-DOS) oryginalne wydanie było znacznie uboższe. Pierwszy wariant Mor- 
tevielle zawierał niedopracowane intro przedstawiające $\mathrm{w}$ tle posiadłość, a na pierwszym planie - narciarza oraz czaszkę. Po fuzji Kyilkhoru z Langlois plansza tytułowa uległa jednak zmianie. W nowym wydaniu Mortevielle pojawiła się już stylowa, utrzymana w sepii postać detektywa Jérôme’a Lange’a, ewidentnie wzorowana na kanonicznym wizerunku Humphreya Bogarta z filmu Wielki sen (Hawks 1946). Ponadto o ile Mortevielle w wersji na Sinclaira QL można było obsługiwać jedynie przy pomocy ograniczonego parsera (liczącego około stu słów), małżeństwo Langlois dokonało w pierwotnym materiale jeszcze dwóch istotnych zmian. Pierwszą z nich było wprowadzenie interfejsu point-and-click, który dzięki rozwijanemu menu z czynnościami możliwymi do wykonania znacząco ułatwiał poruszanie się w świecie gry. Drugą - syntezator głosu, odczytujący wypowiedzi bohaterów gry.

Kolejna część przygód detektywa Lange’a, Maupiti Island, została zaprojektowana przez scenarzystę Sylvaina Bruchona (Bruchon 1991). Za reżyserię odpowiadali jednak głównie Bruno Gourier oraz Jean-Luc Langlois; w procesie produkcyjnym uczestniczył również Christian Droin. Ilustrator Dominique Sablons stworzył około 120 dopracowanych ilustracji do gry, a atmosferyczną ścieżkę dźwiękową do Maupiti Island skomponował André Bescond (Maupiti Island 1989). Tym samym obie gry, zważywszy na czas ich powstania, wyróżniały się nowoczesnym wykonaniem, jednak jak się przekonamy, skrywały zarazem odniesienia do mrocznej przeszłości Francji.

\section{Narracja audiowizualna}

Jednym z powodów tych odniesień była przyjęta przez Lankhor konwencja detektywistycznego filmu noir. Już wspomniany ekran ładowania Mortevielle dostarcza wskazówek ku interpretacji gry w duchu kina czarnego. Nie chodzi tutaj jednak w przypadku obu gier o oczywiste wizualne naśladownictwo amerykańskich filmów kryminalnych, gdyż w Mortevielle oraz Maupiti Island wprowadzone zostają hitchcockowska figura MacGuffina oraz emblematyczny dla kina noir portret „kobiety upadłej".

Akcja Mortevielle rozpoczyna się, gdy Lange otrzymuje od swojej wieloletniej przyjaciółki, Julie Defranck, list z zaproszeniem do tytułowej posiadłości. W momencie przybycia Lange’a na miejsce okazuje się jednak, że Julie jest martwa. Jej odejście staje się okazją do przeprowadzenia śledztwa w sprawie zmowy milczenia, jaka panuje pomiędzy poszczególnymi członkami rodu Defrancków. Gracz może podejrzewać, że ma na celu rozwikłanie sprawy śmierci Julie. Tyle że okazuje się, że jej zgon - wbrew konwencji typowych powieści detektywistycznych - był jak najbardziej naturalny. Tak naprawdę śmierć denatki staje się typowym dla czarnego kina MacGuffinem. Stanowi niejako zachętę do dalszych poszukiwań, które prowadzą ku znacznie mroczniejszej tajemnicy, aniżeli wydaje się na początku. 
Podobnie przedstawia się sprawa w przypadku gry Maupiti Island, która rozgrywa się w 1952 roku na terenie niewielkiego polinezyjskiego atolu Maupiti. Lange trafia na tytułową wyspę, gdy dowiaduje się, że tajemnicza „dama w czerni” porwała mieszkankę atolu Marię. Całe śledztwo polega na tym, żeby odnaleźć tę postać, której tajemniczość rodzi nieuchronne skojarzenia $\mathrm{z}$ femmes fatales z kina noir. Aż do pomyślnego zakończenia gry, polegającego na znalezieniu drogocennego skarbu ukrytego w środku dżungli, nieznana jest tożsamość głównej antagonistki. Rozbudzone przez grę oczekiwania gracza zostają ironicznie potraktowane przez twórców. W finałowej tajnej wiadomości otwartej przez Lange'a ujawnione zostaje, że niemożliwa do odnalezienia postać to sama Maria.

\section{Wymiar ludonarracyjny}

Oczywiście jednak Mortevielle oraz Maupiti Island są nie tyle opowieściami, ile grami. Rozgrywka w nich toczy się nietypowo, albowiem gracz obserwuje świat mu przedstawiany oczami bohatera, w manierze pionierskiego filmu detektywistycznego Tajemnica jeziora (Montgomery 1947). Kierując Lange'em, gracz zostaje zostawiony samemu sobie. Dysponując w Mortevielle oraz Maupiti Island paskami narzędziowymi widocznymi na górze ekranu, można wydawać sterowanemu awatarowi polecenia $\mathrm{z}$ rozwijanych list o sporych rozmiarach ${ }^{1}$. Jedynie wskazówki dostarczone wraz z instrukcjami do obu gier sugerują, że należy przeszukać pomieszczenia w celu zdobycia dowodów rzeczowych przydatnych w dalszym śledztwie i zdobyć jak najwięcej informacji od obecnych w tychże grach podejrzanych. Mortevielle oraz Maupiti Island jednak rządzą się swoimi prawami. Pomimo że Lange nosi przy sobie rewolwer, zabicie którejś z postaci niezależnych lub obrażenie jej w trakcie dyskusji (np. groźbą) może poskutkować złowrogim stosunkiem zamieszkujących świat przedstawiany osób do bohatera, a nawet śmiercią awatara. Niemile widziane jest również wkradanie się do pomieszczeń, w których przebywają już postacie niezależne. Albowiem przemieszczają się one dowolnie po terenach obu gier; choć nie widać ich sylwetek w momencie eksploracji przestrzeni, to jednak ich obecność w danym pomieszczeniu komunikuje panel po prawej stronie ekranu. Ponieważ czas akcji Mortevielle oraz Maupiti Island jest ograniczony do kilku wirtualnych dni (w praktyce - kilku godzin), nie można w pełni poznać niuansów rządzących obiema grami przy jednym podejściu, nawet mimo że dotarcie na skróty do finału obu programów może zająć mniej niż godzinę.

1 Część poleceń w trakcie rozgrywki jest niekoniecznie użyteczna (np. zjedzenie przedmiotu), ale rozmiar dostępnych opcji wynika z tego, że Mortevielle w pierwotnej wersji na Sinclaira QL była obsługiwana wyłącznie za pomocą tekstowego parsera. Maupiti Island w stosunku do Mortevielle zachowywała pod tym względem ciągłość. 


\section{Le Manoir de Mortevielle - ludonarracyjny wymiar a kontekst społeczny}

W Mortevielle tropem prowadzącym do zakończenia okazuje się relacja Guy, syna Julie. Z jego zeznania wynika, iż jego matka miała przyjaciółkę o imieniu Murielle. Ta nie pojawia się wśród napotkanych postaci niezależnych, a jedyną pamiątką po niej jest jej zdjęcie z Guy. Częściowe rozwiązanie zagadki umożliwia zejście do studni ukrytej za wymownie nazwanym przez twórców „murem milczenia” ( $m u r$ de silence). Zejście na dół, do studni, umożliwia dotarcie do tajnej komnaty. W jej wnętrzu znajdują się przebite włócznią, rozpadające się zwłoki Murielle. Z zeznań poszczególnych członków rodu nie wynika, jakoby przypisywali sobie nawzajem odpowiedzialność za śmierć Murielle. Pełne zrozumienie sprawy utrudnia również samo wytłumaczenie ze strony wdowca po Julie, historyka Léa. Ten wyjaśnia następująco okoliczności śmierci Murielle:

W rzeczy samej, ponad rok temu, pracowałem z Murielle nad odszyfrowaniem rękopisów, które właśnie znalazłem. Moja żona stworzyła analogię między naszą pracą a zniknięciem Murielle, ale nigdy nie miała żadnych dowodów. $\mathrm{Z}$ wyjątkiem tego pierścionka, który znalazła pewnego dnia w moich rzeczach. Pewnej nocy udaliśmy się do tajemniczego przejścia, które odkryliśmy. Murielle zginęła przypadkowo w żelaznej dziewicy. Szybko podniosłem obrączkę, znalazłem skarb i uciekłem. Nie sądziłem, że jeszcze żyje i nic nie mówiłem, bo potrzebowałem pieniędzy. Opłaciłem z tej kwoty wyścigi konne... Teraz odejdź, ponieważ nie jesteś z policji. Zostaw mnie w spokoju! (Lankhor 1987)

Zaraz jednak po odejściu Lange’a z posiadłości pojawia się plansza komunikująca, że Léo popełnił samobójstwo. W Mortevielle - wbrew zwyczajowym normom kryminału - pojawia się motyw śmierci bez sprawcy. Ten motyw da się jednak połączyć z dziedzictwem II wojny światowej. Albowiem w świecie gry wnętrze posiadłości reprezentuje oficjalną przestrzeń, w której można dostrzec herb Defrancków (symbolizującego arystokratyczne korzenie rodu) oraz trzy egzemplarze Biblii (symbolizujące ostentacyjną religijność rodziny Defrancków). Jednakże tajemnicze przejście prowadzące do zwłok Murielle reprezentuje psychoanalityczną przestrzeń wypartego. Przez „wyparte” rozumiem tu pojęcie „społecznej nieświadomości" Ericha Fromma, która skłania społeczeństwo do wybiórczego traktowania wydarzeń społeczno-historycznych (Fromm 1962, 98).

Fromm odwołuje się do pojęcia appeasementu, który zwykle rozpatruje się w odniesieniu do ugodowej polityki brytyjskiego premiera Neville'a Chamberlaina wobec Adolfa Hitlera, lecz który niesie ze sobą dodatkowe znaczenie: sympatię Chamberlaina wobec nazistowskich Niemiec (Fromm 1962, 97). Jako bardziej adekwatny przykład można zacytować właśnie uczestnictwo Francuzów w nazistowskiej wojnie, na lata zatajone na rzecz mitu résistancialisme’u. Tu wracam do jed- 
nego z podejrzanych, Léa, historyka z zawodu. Jego wspomniana wyżej przemowa pod koniec gry może nosić znamiona niewiarygodnej. Ponieważ nikt nie przyznawał się do śmierci Murielle, można uznać, że odpowiedzialność za mroczną tajemnicę posiadłości spoczywała na wszystkich jej mieszkańcach. Posiadłość w Mortevielle staje się więc alegorią powojennej Francji, w której pamięć o minionych wydarzeniach była tak wstydliwa, że najprościej było ją okryć milczeniem.

\section{Maupiti Island - ludonarracyjny wymiar a kontekst społeczny}

Również intryga kryminalna w Maupiti Island stanowi pretekst do ukazania społecznego kontekstu lat 50. XX wieku. Świat przedstawiany w Maupiti Island skłania do analizowania go w kategoriach postkolonialnych oraz reprezentacji tożsamości. Panuje w nim bowiem jasny, patriarchalny podział ról społecznych w obrębie płci. Mężczyźni - Bob, Anton, Bruce, Roy oraz Chris - zajmują się przede wszystkim żeglarstwem. Natomiast reprezentacja kobiecych postaci niezależnych ogranicza się do prostytutek. Najstarsza z nich, Maguy, prowadzi dom schadzek, w którym zatrudnione są prywatna kochanka Boba imieniem Sue oraz świadoma swojego nędznego położenia Anita.

Podczas śledztwa gracz może dowiedzieć się, że na tytułowej wyspie doszło do potrójnego morderstwa. Przyjaciółka Marii, Lucie, zostaje znaleziona naga i martwa na plaży; ten sam los spotyka Chrisa - brytyjskiego agenta polującego na Marie - oraz tubylca imieniem Juste. Za wszystkie trzy morderstwa odpowiedzialny jest żeglarz imieniem Roy, notabene kochanek Marie. Na polityczne tło Maupiti Island nakierowuje gracza fotografia kobiety w bransoletce i nazistowskim mundurze, mierzącej z pistoletu. To właśnie nią jest Marie. Pościg Chrisa za nią można uzasadnić jej zbrodniami ludobójstwa (notatka Chrisa zawiera zapisek o Marii: „Pogromczyni plemienia Judy”, co sugeruje jej udział w Zagładzie), uwikłaniem w powojenny handel bronią w Erytrei oraz sprowadzaniem niewolnic seksualnych z Dżibuti. Jest to - tak jak w Mortevielle - trop wiążący grę z echem II wojny światowej, z tym, że bardziej mizoginistyczny. Płeć żeńska albo stanowi w grze zagrożenie, albo zostaje zmuszona do zaspokajania męskich popędów seksualnych. Obraz sytuacji wydaje się znajomy, jeśli odnieść go do literatury i filmu noir, w których przedstawienie kobiety jako „ladacznicy” lub zguby dla mężczyzny było powszechne (Spicer 2002, 90-91).

Wymienionych protagonistów gry łączy jednak jedna wspólna cecha: europejskie pochodzenie i jasny kolor skóry. Tymczasem w Maupiti Island jest jeszcze jedna postać, której nie da się utożsamić ani z „żeglarzem”, ani z „prostytutkami”. Prostoduszny Polinezyjczyk Juste w Maupiti Island figuruje jako ostatni tubylec, który nie został unicestwiony przez białych przybyszy z państw Okcydentu. Oczywiście należy mieć na uwadze, że postać Juste’a jest konstruktem stworzonym przez białych pracowników Lankhoru, dlatego też ucieleśnia on stereotyp irracjonalnego, „niewinnego dzikusa”. Jednakże sposób, w jaki Lankhor wplótł wątek 
Juste’a w treść całej gry, wydaje się nietuzinkowy. O tożsamość Juste’a, nieskażonego zachodnią ideologią, toczy się wojna kulturowa pomiędzy dwiema kobietami: Maguy a Anitą. Pierwsza z nich, gorliwa katoliczka strzegąca okcydentalnej wizji świata, a zarazem podległa patriarchatowi, wręcza Juste’owi Biblię. Nie bez powodu. Ewangelizacja za pośrednictwem Pisma Świętego, jak zauważa irlandzki teolog Michael Prior, była „usprawiedliwieniem całego przedsięwzięcia podboju” ludów nieeuropejskich, które europejscy koloniści traktowali jak wrogów na miarę biblijnych Kananejczyków (Prior 1999, 89). Dla odmiany Anita, reprezentując marksistowską krytykę postkolonialną, próbuje uświadomić Juste’a o jego położeniu za pośrednictwem Manifestu komunistycznego. Zwykła prostytutka, znajdująca się na dnie drabiny społecznej i będąca pod wpływem ideologii komunistycznej, stara się zawrzeć taktyczny sojusz z uciemiężonym przedstawicielem Trzeciego Świata przeciwko okcydentalnemu porządkowi społeczno-gospodarczemu.

Trzeci Świat wybiera jednak „trzecią drogę". Juste nie czyta ani Biblii, ani Marksa, a najbardziej pasjonuje go magazyn erotyczny ze zdjęciami nagich kobiet. Innymi słowy, Juste zostaje uwiedziony przez kapitalistyczną kulturę masową, tracąc swą podmiotowość jako Inny, a zatem wyrzekając się związków z przeszłością tubylczej populacji Maupiti. W wyniku tego zostaje zamordowany przez niechlujnego i chciwego Roya, stając się „ostatnim z Maupiti” - jak Anita opisuje stan zniszczenia podmiotowości Innego. Ponieważ Roy działa na zlecenie nazistki Marie, kolonializm w Maupiti Island wiąże się z nazizmem. Trudno się temu dziwić, gdyż jak przekonuje Jean-Louis Vullierme (2016), europejskie zdobycze kolonialne wiązały się z eksterminacją first nations i logicznie zapowiadały hekatombę okresu II wojny światowej.

\section{Wnioski}

Przedstawiona analiza obydwu gier Lankhoru pozwala wykazać uwikłanie Mortevielle oraz Maupiti Island w przeszłość historyczno-społeczną Francji. Muszę tu oczywiście zaznaczyć, że w chwili wydania gry brakowało takich dyskursywnych interpretacji jak powyższa. Wspomniane gry Lankhoru wpisywały się jednak w szersze zjawisko rewizjonizmu historycznego, znamionowane przez serię Meurtres autorstwa konkurencyjnej wytwórni Cobra Soft. Trzeba mieć wszak na uwadze, że o ile np. w Meurtres à grande vitesse (Cobra Soft 1985) pojawiała się postać wydana przed laty Gestapo przez obecnego senatora, a Meurtres sur l'Atlantique (Cobra Soft 1986) dokumentowała rozwój faszyzmu w Europie przed II wojną światową z aluzją do wzrostu popularności Frontu Narodowego, o tyle gry Lankhoru nie były tak bezpośrednie pod względem retorycznym. Nawet jeśli Mortevielle i Maupiti Island nie komunikowały bezpośrednio zaangażowania politycznego, to niewątpliwie były znakami swego czasu. 


\section{Bibliografia}

Alloula, Malek (1986), The Colonial Harem, Minneapolis: University of Minnesota Press.

Austin, Guy (2008), Contemporary French Cinema, Manchester-New York: Manchester University Press.

Brisou, Mathieu (1987), Mortville Manor, „Tilt”, nr 48, s. 26-27.

Bruchon, Sylvain (1991), Sous le soleil de Maupiti, „Tilt”, nr 94, s. 98.

Cobra Soft (1985), Meurtre à grande vitesse [Amstrad CPC], Francja: Cobra Soft.

Cobra Soft (1986), Meurtres sur l'Atlantique [Amstrad CPC], Francja: Cobra Soft.

Coulon, François (1989), Le grand zoo: Bruno Gourier, „Joystick Hebdo”, nr 10, s. 26.

Fromm, Erich (1962), Beyond the Chains of Illusion, New York: Simon and Schuster.

Gołuński, Tycjan (2016), Change sans risque? Kino francuskie po Nowej Fali (19681984), [w:] Tadeusz Lubelski, Iwona Sowińska, Rafał Syska (red.), Kino epoki nowofalowej, Kraków: Towarzystwo Autorów i Wydawców Prac Naukowych Universitas, s. 963-1054.

Hautefeuille, Olivier (1990), Maupiti Island. „Tilt”, nr 85, s. 13.

Hawks, Howard (1946), Wielki sen [DVD], Stany Zjednoczone: Warner Bros.

Jackson, Julian (2001), France: The Dark Years, 1940-1944, Oxford: Oxford University Press.

Jameson, Fredric (1996), Postmodernizm i społeczeństwo konsumpcyjne, przeł. P. Czapliński, [w:] R. Nycz (red.), Postmodernizm. Antologia przykładów, Kraków: Wydawnictwo Baran i Suszczyński, s. 190-213.

Lankhor (1987), Le Manoir de Mortevielle [Amiga], Francja: Lankhor.

Lankhor (1990), Maupiti Island [Amiga], Francja: Lankhor.

Lankhor.net (b.d.), Les anciens jeux de Lankhor (dostęp 22 lutego 2020).

Malausa, Vincent (2002), Le plus beau jeu du monde, „Cahiers du Cinéma”, specjalny, s. 52.

Maupiti Island (1989), „Génération 4”, nr 17, s. 212-213.

Montgomery, Robert (1947), Tajemnica jeziora [DVD], Stany Zjednoczone: Metro-Goldwyn-Mayer.

Morris, Alan (1992), Collaboration and Resistance Reviewed: Writers and the "Mode retro" in Post-Gaullist France, London-New York: Berg.

Pérez-Latorre, Óliver, Mercè Oliva, Reinald Besalú (2017), Videogame Analysis: A Social-Semiotic Approach, „Social Semiotics”, nr 27(5), s. 586-603.

Prior, Michael (1999), The Bible And Colonialism: A Moral Critique, Sheffield: Sheffield Academic Press.

Spicer, Andrew (2002), Film Noir, London: Routledge.

Vullierme, Jean-Louis (2016), Lustro Zachodu. Nazizm i cywilizacja zachodnia, Kraków: W.A.B. 
Filip Jankowski

\title{
Rozrachunek z przeszłością historyczną Francji na przykładzie gier Lankhoru
}

\author{
Abstrakt
}

Celem artykułu jest unaocznienie, w jaki sposób przeszłość historyczna państwa francuskiego mogła być poddawana w grach cyfrowych rewizji. Na użytek badań wykorzystane zostały dwie gry studia Lankhor (Le Manoir de Mortevielle oraz Maupiti Island), zanalizowane za pomocą społeczno-semiotycznego modelu analitycznego Ólivera Péreza-Latorrego, Mercè Oliwy i Reinalda Besalú. Rezultaty badań pozwalają stwierdzić obecność w obu grach odniesień do kolaboracji Francuzów z Niemcami w ramach Państwa Vichy (Mortevielle) tudzież do ludobójczych praktyk kolonialnych wobec tzw. tubylców (Maupiti Island).

Słowa kluczowe: kolonializm, Państwo Vichy, francuskie gry cyfrowe, analiza gier cyfrowych, gry wideo

\section{Settling the French Historical Past: The Example of Lankhor Games}

\section{Abstract}

The aim of the article is to illustrate how the historical past of France could be revised in digital games. Two Lankhor games (Le Manoir de Mortevielle and Maupiti Island) were used for research purposes, analyzed using the social-semiotic analytical model of Óliver Pérez-Latorre, Mercè Oliva and Reinald Besalú. The results of the research allow us to find in both games references to French collaboration with Germans within the Vichy (Mortevielle), as well as to genocidal colonial practices against the so-called natives (Maupiti Island).

Keywords: colonialism, Vichy State, French digital games, digital game analysis, video games 
Filip Jankowski (ur. 1993) - historyk gier, filmoznawca. Doktorant na Wydziale Zarządzania i Komunikacji Społecznej UJ, absolwent Instytutu Sztuk Audiowizualnych UJ. Specjalizuje się w badaniu dziejów francuskich gier cyfrowych, z naciskiem na ich tło społeczno-historyczne. Publikował między innymi w „Homo Ludens” oraz „Games and Culture”. 